\title{
Compensation ecogenic harm: experience of legal regulation
}

\author{
Yulia Sergeevna Cherepantseva ${ }^{1, *}$, and Elena Mikhailovna Ruzaeva ${ }^{2}$ \\ ${ }^{1}$ Department of Labor and Social Security Law of the Orenburg Institute (branch) of the O.E. \\ Kutafina (Moscow State Law Academy), Orenburg, Russia \\ ${ }^{2}$ Department of Civil Law and Procedure, Orenburg State University (OSU), Orenburg, Russia
}

\begin{abstract}
The article is devoted to the elucidation of the problems of compensation for environmental damage caused to human life and health by the adverse effects of the environment caused by radiation exposure. Based on the fact that the radioactive factor is the primary cause causing ecogenic harm, a definition of such harm is given, its content and characteristics are disclosed, the provisions of the current legislation that enshrine the main legal means to compensate for the harm caused to the victims are analyzed.
\end{abstract}

\section{Introduction}

A healthy and supportive environment is one of the main conditions for a safe human existence. The problem of environmental pollution is most clearly identified before mankind due the rapid development of industry and development of new technologies. Wherein, spheres were opened that were completely unknown to people, and the consequences of their use were only assumed. One of them was radiation. Being both a blessing and a disaster, radiation has confidently entered modern life, becoming an integral part of it.

It is impossible not to notice that nature is characterized by natural pollution by radiation. It comes from the earth's crust, which contains a certain amount of radioisotopes. Radiation hits the earth from space. However, the increasing anthropogenic impact associated with man-made disasters, testing of nuclear weapons, operation of atomic and nuclear enterprises and their radioactive waste has become the main factor in the negative impact on the environment. The number of territories where the dose rate from the radiation of technogenic radionuclides is dozens of times higher than the background that existed in the pre-atomic period is steadily growing [1]. Unfortunately, we have to admit that of all known types, radiation pollution remains one of the most dangerous and causes a social risk to the life and health of the population. According to the conclusions of the UN Scientific Committee on the Effects of Atomic Radiation (2000), the pathologies caused by radiation after the accident at the Chernobyl nuclear power plant are thyroid cancer, blood diseases, anomalies in the development of children in parents exposed to the factors of a radiation accident. In the remote period after the accident, the pathology of the digestive system

\footnotetext{
*Corresponding author: chus1973@mail.ru
} 
ranks third in the structure of primary morbidity, second only to diseases of the organs of the cardiovascular and respiratory systems [2]. The reason for this is the penetrating effects of radiation. As a result of the release of radioactive substances, damage to the territory, objects and all living organisms is caused at a considerable distance.

Consideration of the issues of compensation for environmental damage has become the subject of study of legal science in connection with development of environmental legislation as a result of major radiation accidents that have occurred. However, for a long time, the definition of environmental harm caused to a person, including as a result of radiation exposure, its volumes and methods of compensation, was not included in the sphere of legal study, remaining the prerogative of economics, medicine and sociology. In this connection, this article is an attempt to fill the gap, substantiate the legal structure of environmental harm and assess the formed methods of compensation for such harm from the standpoint of a critical analysis of the current legislation in the area under consideration. As a result, the main positions are determined that ensure protection of violated rights, among which the primary is the right to life and health protection.

\section{Materials and Methods}

The issues of environmental pollution and the problems of radiation disasters from the point of view of their social component, in scientific and practical terms, have been studied since the middle of the last century. Over the years of fruitful scientific study, considerable theoretical, methodological and empirical material has been accumulated. However, its entire resource is related either to the study of the catastrophe itself as a phenomenon (natural or technogenic), or its components, which determine the direction of social processes, leaving outside the legal impact on the relevant social relations in order to regulate them. The fact that it is in the law that the methods and means of influencing the consciousness and behavior of people are determined, determined the choice of study methods.

The methodological basis of the study presented in the article is formed by the dialectical method of understanding radiation accidents and catastrophes as social and legal phenomena, scientific analysis and synthesis, with the help of which the legal structure of environmental harm is developed and its concept is determined. The characteristics of ecogenic harm are revealed on the basis of the structural-functional method. Use of such private scientific study methods as specific sociological and comparative legal methods allowed the author to reveal the legal means of compensation for the harm caused to a person, his/her life and health, and to determine the effectiveness of their legal regulation. Wherein, all the selected methods for obtaining specific results complement and develop fundamental knowledge on the problem under consideration.

\section{Results and Discussion}

The modern world has become an atmosphere where people cannot feel reliably protected. Inability to live peacefully, work productively, have a family and children, not worry about their health and the health of their loved ones and many other factors create a stressful situation that significantly affects a person's life. The growing number of attacks on human life and health is due to various reasons. One of them was the use of such an energy source as radiation. Despite the long period of its presence in the life of society, the consequences of its influence on a person have not been fully studied. Unfortunately, we are forced to admit that when using it, the state cannot guarantee absolute security. Therefore, the main task is to develop effective ways to minimize the possible harmful effects caused by the 
adverse effects of radiation. In this case, a special role belongs to legal regulation, since through creation of legal norms, real and proper fulfillment of the requirements prescribed by the legislator is achieved. One of them is compensation for harm caused.

It shall be noted that there is extensive legislation governing the rules and procedures for causing harm by negative changes in the natural environment caused by human activities. Formulation of the issue of compensation for harm in the rule of law shall begin with an analysis of the Constitution of the Russian Federation. The Basic Law securing the rights of citizens proclaims the right to a favorable environment, reliable information about its condition and to compensation for damage caused to their health or property by an environmental offense (Article 42).

The Federal Law "On Environmental Protection" in the provisions of Article 11 reproduces the constitutional rule supplementing it with Article 79 that establishes the rules for compensation for harm caused to health and property of citizens as a result of violation of legislation in the field of environmental protection. So, according to part 1 of this Article, harm caused to the health and property of citizens by the negative impact of the environment as a result of economic and other activities of legal entities and individuals is subject to compensation in full.

In the scientific literature, the harm caused to the environment is commonly referred to as environmental harm. Wherein, from the point of view of adverse consequences for humans, it is defined as ecogenic. However, at present there is no consensus in the legal doctrine on the definition of this type of harm. From the standpoint of differentiation by the object of impact, some researchers distinguish humanitarian environmental harm, suggesting that it is inflicted on a person for whom environmental protection activities are carried out [3]. A number of authors, for example, do not consider ecogenic harm as an independent type and include it in the composition of environmental harm, considering them synonymous with each other [4]. This point of view seems to us not objective, since it is obvious that initially harm is caused directly to the environment, and the negative changes already caused by this, which have occurred as a result of unfavorable anthropogenic impact (and radiation exposure is no exception here), significantly affect the life, health of people living in the affected area, their property. This, in turn, allows us to consider environmental damage to be derived from environmental damage. Diseases, any other health disorders or a threat to life, including potential ones, reduced working capacity, forced consumption of contaminated products and natural resources, the need to change the place of residence and settle in a new place, etc., are characteristic of ecogenic harm. In this aspect, we share the point of view about the ecological nature of ecogenic harm [5]. Based on such a statement, we believe that among the specific features inherent in ecogenic harm is the fact that it is caused, first of all, to a person, i.e. human life and health. In addition, it is expressed in losses and damages (including non-material ones) that arise from the victim. It is not unreasonable to consider that moral harm can also be included in the composition of environmental damage. In fact, moral harm shall be considered as a form (or element) of environmental harm, since as a result of exposure to radiation, the victims, of course, suffer moral suffering associated with moving to another area, the risk of having children with congenital anomalies or the inability to have children at all, or physical suffering caused by diseases, both their own and their children, or, even worse, their death. There are enough examples of such court cases over the long history of combating radiation consequences. Although among them there are both positive, which allows us to come to the above conclusions (the Nazhmutdinovs' case on the recovery of moral damage from the Mayak PA in the amount of 50 million rubles, the decision of the Ozersk City Court of the Chelyabinsk Region on April 7, 1997), and negative (refusal to recover moral damage in the amount of 5 million rubles in the Khasanovs' case, 2013). 
Considering the above circumstances, we believe that harm caused to a person as a result of negative changes in the environment, resulting in damage to health, its loss or loss of life, the costs of restoring health and compensation to the victims of the losses incurred, as well as their moral experiences and physical suffering, shall be recognized as ecogenic.

The problem of compensation for environmental damage caused by radiation exposure is legally complex. On the one hand, it is characterized, as already mentioned, by ecological nature; on the other hand, it is anthropogenic, since caused to a person, his/her health, the state of future generations.

Focusing on the general issues of compensation for environmental damage, we note that it is carried out according to the rules of several branches of Russian law, in connection with which it is considered one of the most important intersectoral institutions, due to the fact that it includes the norms of civil and environmental legislation [6]. From the standpoint of civil law regulation, Articles 1064-1098 of the Civil Code of the Russian Federation give us an idea of the harm caused to the person and property. However, considering the specifics of the harm caused to the environment, one cannot but emphasize use of the norms of environmental legislation, which directly indicate its form, inflicting subjects, sizes, methods of calculating compensation, and etc. Therefore, it is possible to clearly trace the ecological specifics of the harm that is compensated in the manner of civil law relations. Environmental legal regulation enshrines the principle of compensation for damage caused in full, which indicates that the victim shall receive full compensation, regardless of the limits of civil liability.

The general provisions of civil law also establish the rule that damage is compensated by the person who caused it. Wherein, being formed as a result of radiation exposure as a special factor, further individualizes it. Therefore, according to Articles 56 and 57 of the Federal Law "On the Use of Atomic Energy", a specific feature of the damage caused by radiation exposure is its provision not only by the inflicting enterprise, but also by the state. Wherein, the operating organization itself shall be obliged to have financial security for the limit of civil liability and compensates for the damage caused within this scope, and compensation for damage to the full amount (i.e., over the volume established for the economic entity) is provided by the state.

When solving the issues of compensation for harm associated with the adverse impact of the environment, the methodology traditionally used is the evaluation of harm caused to human health. When assessing the physical impact, the damage to the population is monetized, i.e. the cost equivalent is determined. For example, in the EU countries the Impact parthway appoarch or IPA method is used as an official method for determining the cost of the equivalent of damage to public health from adverse environmental factors [7]. An analysis of the current legislation shows that the Russian Federation has also followed the path of determining the damage caused in monetary terms. Although, at first glance, this looks somewhat illogical - while proclaiming that life and health are priceless, the price, nevertheless, is determined by it. However, this is precisely the specificity of the ecogenic damage caused by radiation, when the state assumes the responsibility to provide assistance to the victims.

According to the Resolution of the Plenum of the Supreme Court of the Russian Federation of November 30, 2017 No. 49 "On Some Issues of the Application of Legislation on Compensation for Harm Caused to the Environment", cl. 17 defines two forms of compensation - in kind, if it is objectively possible, and if irreplaceable and (or) hard-to-recover losses - in monetary form. Unfortunately, we have to state the fact that the monetary form of compensation for environmental damage has long been a source of criticism. First of all, because the funds received as compensation for harm from violators of environmental legislation are not isolated and often, having become part of the federal budget, can be spent on purposes other than environmental restoration. Its opinion on this 
issue was expressed by the Constitutional Court of the Russian Federation, which considers that the harm caused to the environment is often irreparable, and the state has the right to send the received sums of money to the budget as compensation, and not the restoration of the environment (Resolution of the Constitutional Court of the Russian Federation of June 2, 2015 No. 12-P). Wherein, the monetary form is additional and compensates only that part that cannot be reimbursed in kind.

The specificity of the harm caused by radiation exposure is its classification as irreparable and incalculable. This circumstance determines the need for a special approach to ensure the victims of the restoration of violated rights. In view of this, based on the principle of the maximum possible use by the state of the funds at its disposal, it can be said that the main way to compensate for environmental damage is monetary and other material benefits and compensation for damage caused. The lack of legal means possessed by civil, administrative, criminal and other sectoral legislation allowed the highest judicial body to offer a constitutional justification for the legal mechanism of social protection of citizens affected by radiation as aimed at fulfilling the constitutional and legal obligation arising from the right to a favorable environment, reliable information on its condition and on compensation for damage caused to health or property by an environmental offense [8]. Due to the fait accompli of radiation exposure, we are talking purely about compensation, because it is almost impossible to prevent social risk. Raising the question of prevention is permissible only when its impact (including on humans) is minimized. That is why the choice of such a legal mechanism is not accidental and is due to the fact that state guarantees are possible only within the framework of public law models obliging the state to provide a citizen with social benefits and services in the manner and under the conditions established by law [9]. The targeted orientation of these legal means most of all ensures compensation for the unfavorable consequences that have arisen among citizens, rather than other methods. Protection in this case acts as a measure of legal compensation for lost resources (material, spiritual and others). To ensure the effectiveness of such measures, they are enshrined in the rule of law, normative legal acts are adopted that provide for provision of compensation and benefits to victims. Along with environmental legislation, social legislation has been formed, the main purpose of which is to compensate for the damage to the health of victims of radiation and provide them with additional benefits (medical, housing, labor, etc.). The choice of such legal means is not accidental. So, for example, according to the All-Russian classifier of information on social protection of the population, benefits are ranked among the most effective measures for its implementation [10]. Support through provision of benefits aims to provide protective measures in order to preserve the life and health of the victims. Moreover, according to the Constitutional Court of the Russian Federation, the state, based on the principle of the maximum possible use of funds for compensation, can choose any methods (benefits, monetary or material compensation). The main thing is that it is unacceptable to cancel or reduce the previously recognized scope (Determination of the Constitutional Court of the Russian Federation of June 14, 2006, No. 273-O). In this understanding, the achieved level of protection of the rights and freedoms of victims, guarantees of their social protection will be ensured.

The main regulatory legal act which embodied all known types of social protection of affected citizens was the Law of the Russian Federation of March 15, 1991, No. 1244-I "On Social Protection of Citizens Exposed to Radiation as a result of the Chernobyl Disaster" (hereinafter referred to as the "Law on the Chernobyl NPP"). Initially, its norms were calculated for all known cases of negative radiation impact that took place in the history of our state. In fact, it can be called a universal act, the effect of which extends both to citizens affected by the results of the activities of enterprises producing radiation substances (for example, the Mayak Chemical Plant), and to participants in nuclear weapons tests or radiation accidents (for example, tests at the Totsk test site in the Orenburg region, the 
Novaya Zemlya archipelago, and etc.). Only in 2002, in connection with adoption of Federal Law of January 10, 2002 No. 2-FZ "On Social Guarantees to Citizens Exposed to Radiation as a Result of Nuclear Tests at the Semipalatinsk Test Site", the relevant category of victims was removed from the scope of the Law on the Chernobyl Nuclear Power Plant. Despite more than 30 years of practice in application of the relevant legal norms, their effectiveness is one of the problems of ensuring full protection of victims. Its application revealed insufficient and irregular funding of social protection measures, obvious failures in the programs of medical assistance and treatment of victims, providing them with housing, and etc. Therefore, a huge number of citizens' appeals to the courts for protection of their rights has become an important step towards improving the legal means of compensating for environmental damage caused by radiation exposure.

The specificity of the type of harm under consideration shall also be recognized that Clause 22 of the above-mentioned Resolution of the Plenary Session establishes an exception for this type of harm in terms of the limitation period. If, according to the general rule, the limitation period for compensation for environmental damage is 20 years (Clause 22 ), then the damage caused by radiation exposure is compensated for within three years from the day when the person learned or should have learned about the violation of his/her right (Article 58 of Federal Law of November 21, 1995, No. 170-FZ "On the Use of Atomic Energy").

\section{Conclusion}

The state of the environment is a matter of increasing concern every year. Its pollution as a result of anthropogenic impact poses a real threat to the population. Among the most dangerous factors causing negative changes in the environment and adversely affecting human health and life, radiation exposure should be called. The radiation accidents and catastrophes that occurred in different years of the development of our state became the starting point in understanding the danger of radiation for humans. Society has come to understand that modern technologies and production do not forgive the lack of control over risk. The radiation threat as a powerful negative factor undermines the vital resources of the territories and the people living in them. Moreover, in its overwhelming majority, the effect of radiation is already a fait accompli, which was either impossible to prevent from the very beginning (as, for example, in the case of the disaster at the Chernobyl nuclear power plant), or the very fact of radioactive training received by people was not given importance and no measures were taken to its prevention (the activities of Mayak Production Association, testing of atomic weapons at the Semipalatinsk or Totsk test sites, etc.).

Features of compensation for harm to a person caused by adverse changes in the environment, first of all, lies in the specifics of harm. Such harm is ecogenic. It is derived from environmental harm and is characterized by the fact that it is caused directly to a person, leads to damage to health, its loss or loss of life, causes the cost of restoring health and compensation for victims of losses incurred, and is also expressed in moral experiences and physical suffering.

The main task facing the legislator in the event of ecogenic damage is development of effective legal means to compensate as much as possible for the losses incurred. According to general rules, damage caused to the environment by radiation exposure is compensated for under the rules of civil, environmental, administrative and other legislation. However, due to the special danger of such an impact, which is recognized as a social risk for a person, his/her life and health, for the most complete compensation, public law is used.

Recognizing responsibility to citizens for the consequences of radioactive contamination of the environment, the state adopts normative legal acts aimed at protecting them, in the provisions of which legal means are enshrined that make it possible to 
compensate for environmental damage. However, not all of them can be considered effective and efficient. There are many reasons for this. In this connection, the legal problems of compensation for environmental damage caused as a result of exposure to radiation continue to remain complex, both in theory and practice. Most significantly, because they affect the most valuable thing for a person - his/her life and health.

\section{References}

1. A. V. Korsakov, A. S. Domahina, V. P. Troshin, E. V. Geger, Human Ecology, 7, 4-14 (2020)

2. S. V. Dudarenko, S. N. Lopatin, O. V. Leonteva, Human Ecology, 1, 11-16 (2020)

3. E. A. Zhulay, E. G. Cherkashina, Bulletin of the AmSU, 42, 32-36 (2008)

4. M. I. Vasilyeva, State and Law, 10, 26-36 (2008)

5. M. M. Brinchuk, Ecological Law, 472 (2005)

6. A. Ya. Ryzhenkov, Bulletin of the University named after O. E. Kutafina, 3, 77-85 (77) (2020)

7. V. V. Dyadik, N. V. Dyadik, E. M. Klyuchnikova, Human Ecology, 2, 57-64 (2021)

8. Yu. S. Cherepantseva, Legal positions of the Constitutional Court of the Russian Federation as the basis for development of a system of social protection of citizens affected by the effects of radiation, For Workers' Rights! Protection of the social and labor rights of workers in a changing world: opportunities and limitations: materials of the Sixth International Scientific and Practical Conference, Yekaterinburg, December 9-10, 169-173 (2020)

9. E. A. Istomina, M. Yu. Fedorova, Legal mechanism of social risk management, 240 (RANEPA, Yekaterinburg, 2018)

10. A. G. Repyev, Bulletin of St. Petersburg University. Right, 12(1) (2021) 